\title{
Corruption in the Capital Construction Sector in Vietnam - Characteristics, Reality, Tricks and Preventing Solutions
}

\author{
Nguyen Hoang Long \\ Department of Economic Police, People's Police University, Ho Chi Minh City, Vietnam \\ Email address: \\ Longnguyenhoang201@gmail.com \\ To cite this article: \\ Nguyen Hoang Long. Corruption in the Capital Construction Sector in Vietnam - Characteristics, Reality, Tricks and Preventing Solutions. \\ International Journal of Law and Society. Vol. 3, No. 3, 2020, pp. 114-122. doi: 10.11648/j.ijls.20200303.16
}

Received: July 15, 2020; Accepted: July 27, 2020; Published: August 18, 2020

\begin{abstract}
Investment in capital construction is one of essential demand of a country and takes the role of boosting its economy. In recent years, Vietnam has taken an emphasis on basis construction for the target of economy growth contributing to the work of industrialization and modernization, meeting the requirements of the science and technology revolution in the $4^{\text {th }}$ age. Capital construction, however, has recently revealed many limits and faults coming from weakness in management of the authorities as well as from directly the undertaking units of construction. This article is based on assessment of corruption in the field of capital construction in Vietnam and tricks of the criminal in corruption and how they can hide their violation and legalize the corrupting assets from which the composer suggested synchronous solutions in preventing and fighting the crime of corruption in capital construction. The article inherits the previous author's studies on corruption in the field of capital construction and updates the new methods and tricks of crimes in the field of capital construction in recent times, and new issues need to be raised to improve the effectiveness of preventing corruption in the capital construction sector in Vietnam in the coming years.
\end{abstract}

Keywords: Capital Construction, Corruption, Situation Characteristics, Methods and Tricks, Prevention, Vietnam

\section{Introduction}

In the development history of human society, the existence of social power is an indispensable to ensure the existence of the community. In that community, people instinctively rise to satisfy the material and spiritual needs. The uneven rise of each people group leads to social division. Accordingly, the private property system was born and the social power which was inherently pure gradually became corrupted. In such circumstances, some people have taken advantage of the community power given to them, appropriating publicly or unlawfully, to meet public needs. The essence of this behavior is corruption [1]. Therefore, corruption is a historical social negative phenomenon, occurring in association with the appearance of private ownership and the appearance of the State. Among the forms of social power, the state power is a form of power very vulnerable to corruption [2]. Therefore, it can be affirmed that corruption exists in all social regimes with different manifestations and levels, depending on the political, economic and social context in each country and territory. in each stage of development.

Corruption is a complex social phenomenon with many different manifestations, so the concepts of corruption also differ in countries and in each approach perspective corresponding to the development in countries and regions. that area. According to the definition of Okafor stated that "social corruption, any action or behavior that is contrary to socially recognized standards and considered negative by some individuals in the commune festival" [3]. Or, according to Oladele's approach, the definition of corruption becomes more complicated when it is considered in terms of classification such as supportive corruption, transactional corruption, extortion, personal corruption. and institutions, traditional and modern corruption, local, national or international corruption, or representative corruption, large as well as petty corruption [4]. Corruption jeopardizes the right choices and keeps the crooks misleading as a discriminatory model for the coming generation, it undermines quality, undermines social and economic development, and at the same time does illegal cultural degradation, thereby reducing market efficiency and increasing the cost of goods and services, promoting inefficient investment, and leading to a decline in the quality of public services and private and actually the worst consequences are not due to bribery but 
because of the potential economic distortions they cause [5]. Hawkins adopted the definition of corruption as defined by Transparency International as "The misuse of delegated power for private gain" [6]; This actually includes not only public authorities, but private interests include issues such as institutional and political interests related to contractors, consultants, suppliers, subcontractors, customers and even supervisors are key players in the infrastructure delivery process.

Although there are many different concepts and expressions, there is a common point that corruption is the behavior of a powerful person or a group of people who take advantage of power for their own gain. In Vietnam, according to the provisions of the Anti-Corruption Law of 2018, it is clear: "Corruption is the behavior of people in positions and powers who abuse that position for self-seeking purposes." [7]. This is a relatively broad and complete concept of the nature of corruption in Vietnam today.

Construction is an industry that produces technical and material facilities, as a prerequisite for a nation's socio-economic development and development. Constructions are often single, require long time, large funding, technical application, advanced technology, involving many aspects of management, affected by climate, natural and risks, force majeure [8]. In recent years, the State management of capital construction investment in Vietnam has achieved many great achievements, the subjects participating in construction activities have also grown and constantly grown, the supervision. of State management agencies and social community, which have been increasingly effective, detected many negative and negative factors in construction investment, contributing to limiting and overcoming violations of law in This area [9].

However, due to the increasing demand for construction, the expanded scope, plus the weak management capacity and the strict observance of discipline and laws of the State of Vietnam have led to losses in many works, affecting construction work in many aspects [10]. In the process of world economic integration, in the coming years, the construction investment situation in Vietnam will continue to thrive, especially the concentration of capital for construction of national key projects [11]. On that basis, corruption crimes in general, the negative situation, corruption in construction investment in particular in Vietnam still contain complex happenings with new methods and tricks; nature, scale will be more sophisticated, complicated and more serious [12]. Therefore, it is necessary to find effective solutions to protect the quality of construction works, especially the works of the century, cultural and artistic works..., to protect capital sources for activities of construction investment and protection of officials (including the protection of prestige and purity of construction industry officials) [13].

\subsection{Research Purposes}

Based on the perspectives on corruption of authors in the world and Vietnam and the role of construction activities in developing countries, including Vietnam in contributing to the development of the one nation's economy. The request put through research is to determine how the reality of corruption in the field of capital construction in Vietnam today is? What is the level of consequence and the prevention activities of the current authorities? From that, it is possible to identify solutions to be taken to minimize corruption in capital construction. This content will be presented in the next section of the study.

\subsection{Research Methods}

The research methodology of this paper basically consists of document search and content analysis of corruption cases in the field of capital construction in Vietnam. The study was conducted with reference to existing theoretical literature, published works and related dissertations. The work is especially focused on reviewing the literature on corruption trends as witnessed in the construction industry. Comprehensive research on related documents on the same topic was done using basic databases and search engines including Google, related works and reviewed articles. other.

\subsection{Research Orientation}

Research on corruption acts in the field of capital construction in Vietnam: the situation of crimes, the number of cases detected, investigated by the authorities, the number of damages caused by corruption in the field of capital construction.

To find practical basic solutions that can be applied in conditions in Vietnam based on the cases occurred and the situation of the struggle of the authorities. At the same time, propose a number of recommendations to improve the effectiveness of anti-corruption in capital construction in Vietnam in the coming time.

\subsection{New Findings of the Research}

Studies by domestic authors have pointed out the situation of corruption crimes in the context of globalization [1] or referring to corruption as a problem of society: causes of corruption and development that some solutions to anti-corruption recently. In addition, some authors have mentioned corruption in the field of construction, but also share common, not a generalized situation of corruption crimes in this regard the current period and the specific measures of the forces in preventing corruption crime in capital construction. The paper is based on the analysis of data summarizing the reports of the authorities involved in the prevention of corruption in capital construction to make assessments on this crime situation, and in-depth analysis of the case occurred in Vietnam over the years and the responsibility of the forces in prevention activities. From which the article has introduced new and feasible solutions in the application of anti-corruption in capital construction in Vietnam. 


\section{The Reality of Corruption Crimes in the Field of Capital Construction in Vietnam During Recent Years}

\subsection{Reality of Construction Investment Activities in Vietnam}

In recent years in Vietnam, the capital construction investment activity has been very strong in order to develop the economy, the Vietnamese government has prioritized public investment in the field of infrastructure, high-speed construction projects, elevated roads, piers, petrochemical refineries, industrial parks to attract more foreign investors [13]. According to BMI research, Vietnam is one of the fastest growing market borders, in which infrastructure investment is always considered a top priority of the Government. Statistics from BMI show that the cost of capital construction accounts for about $25 \%$ of total Government expenditure from $2015-2018$, the growth rate of construction industry in 2019 is $7.23 \%[14]$.

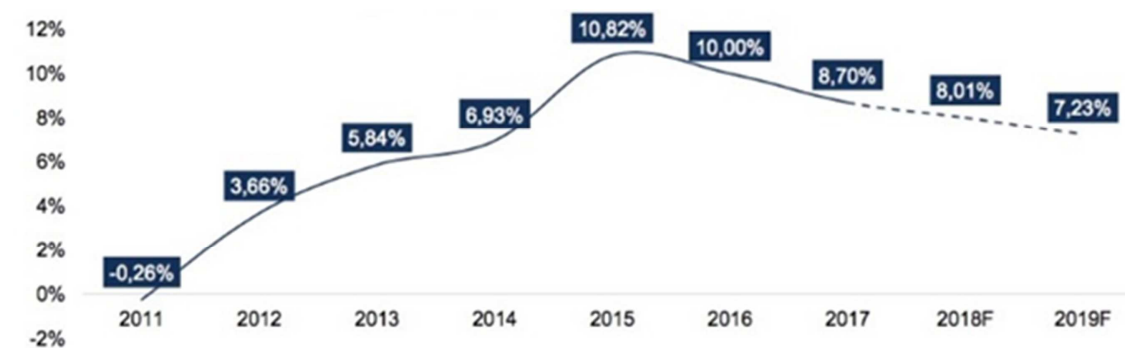

Figure 1. Growth rate of construction industry in Vietnam from 2011 to 2019 (Source: GSO, FPTS, BMI).

The chart in Figure 1 shows that the growth rate of the construction industry in Vietnam for 10 years with the rapid development in the first half of the cross-century and the highest growth rate of $10.82 \%$ in 2015 Then gradually decrease and maintain at $7.23 \%$ in 2019 . This shows that the construction industry in Vietnam in recent years has had a stable growth, contributing to the development of infrastructure. The floor serves the face of the nation's socio-economic life. Besides, the factors that bring growth to the construction industry in Vietnam are the basic macroeconomic economy continues to be stable, the CPI continues to remain low, the total value of FDI continues to rise sharply, especially the last time the US-China trade war partly affected the FDI inflows from China to Vietnam $[9,14]$.

Table 1. Relocation of large corporations to Vietnam as of December 2019. Source: VinaCapital (quoted from Savills Vietnam report).

\begin{tabular}{|c|c|c|c|c|}
\hline Company & Nationality & Status & Locations (expected) in Vietnam & Business \\
\hline Hanwha & KOR & Moved & Hanoi & Producing airplane parts producing \\
\hline yoknum & JPN & Moved & Hanam & Producing parts for motor vehicles \\
\hline $\mathbf{f} \mathbf{u}^{\circ}$ & $\mathrm{CHN}$ & Moved & Long An & Textile \\
\hline & HKG & In moving & Bac Ninh & $\begin{array}{l}\text { Producing headphones and telephone } \\
\text { components }\end{array}$ \\
\hline & $\mathrm{CHN}$ & In moving & Binh Duong & Electronics-TV \\
\hline Fロxcann & TWN & In consideration & Bac Giang, Quang Ninh & Electronics-TV \\
\hline Lenovo. & $\mathrm{CHN}$ & In consideration & Bac Ninh & Electronics and Computers \\
\hline Ninfendo & JPN & In consideration & Unknown & Electronics-Toy accessories \\
\hline SHARP. & JPN & In consideration & Binh Duong & Electronics-Cameras \\
\hline 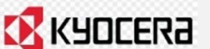 & JPN & In consideration & Hai Phong & Electronics-Printer, photo machine \\
\hline
\end{tabular}

The foreign direct investment (FDI) sector is an important resource contributing to accelerating the development of the country's economy, adding significant capital sources for growth, technology transfer and enhancing export capacity. as 
well as create more jobs and improve living standards for people [15]. In addition, FDI plays a very important role in improving the national competitiveness. For export activities, foreign-invested enterprises have continuously increased and by 2017 , reached nearly 204.5 billion USD and $66.3 \%$ of Vietnam's total export turnover. Thanks to FDI export, the trade balance has not only improved but also created a trade surplus in recent years [16]. According to experts, Vietnam is attracting more foreign investors than ever thanks to tax incentives and low labor costs. The Government of Vietnam also prioritizes public investment in infrastructure, high-speed construction projects, elevated roads, bridge construction, oil refineries, and industrial parks. On the other hand, multinational companies and large corporations from China are strongly promoting the relocation of production to Vietnam instead of China. This will help promote industrial construction and create favorable conditions for contractors in this field. Infrastructure construction is also attracting the great attention of the Government and both domestic and foreign investors $[9,13,14]$.

\subsection{The Situation of Corruption Crimes in the Construction Sector in Vietnam}

In the field of capital construction in Vietnam, corruption manifests itself in various levels and forms. Negative, corruption in the field of capital construction in Vietnam occurs in almost all stages, from project formulation, surveying, design, investment, to construction, acceptance checking, and settlement [15]. According to the statistics of the National Assembly Supervision Delegation, nearly 1,500 investment projects under examination have nearly 180 projects in violation of appraisal regulations; 400 design violations-survey; about 200 related bidding regulations; more than 800 construction wrong designs, types of materials, violations of quality management, acceptance, payment... [17]. According to the report of the Vietnam General Association of Construction shows "Corruption in capital construction investment. popularized and bureaucratic corruption of civil servants. This form of corruption is often organized vertically, if not promptly controlled, it will gradually become deeply corrupt, very difficult to cope with" [18]. Deputy Minister of Public Security of Vietnam-Le The Tiem admitted, the results of detection, investigation and handling of the authorities are still low, the crime rate "hidden" in the field of construction investment is still high [15]. According to Mr. Francesco Checchi-Southeast Asia-Pacific Regional Advisor on Anti-corruption "Global bribery is estimated at US \$ 1,000 billion and corruption worldwide amounts to US \$2,600 billion, accounting for 5\% of annual GDP".

Although the number of cases of corruption in the capital construction sector in recent years was discovered in Vietnam is very large, but the cases investigated by Ministry of Public Security is still limited. According to a report summarizing 10 years of implementation of the Law on Anti-Corruption in Vietnam shows that, during the 10 years from 2010 to 2019 , prosecuted: 1,558 cases $/ 2,780$ defendants, 156 cases $/ 278$ defendants each year, including many big, serious and foreign corruption cases [19]. The chart shows that the number of corruption cases investigated and tried in Vietnam tends to increase significantly in 2016 and 2018 with 203 and 205 cases respectively (Figure 2).

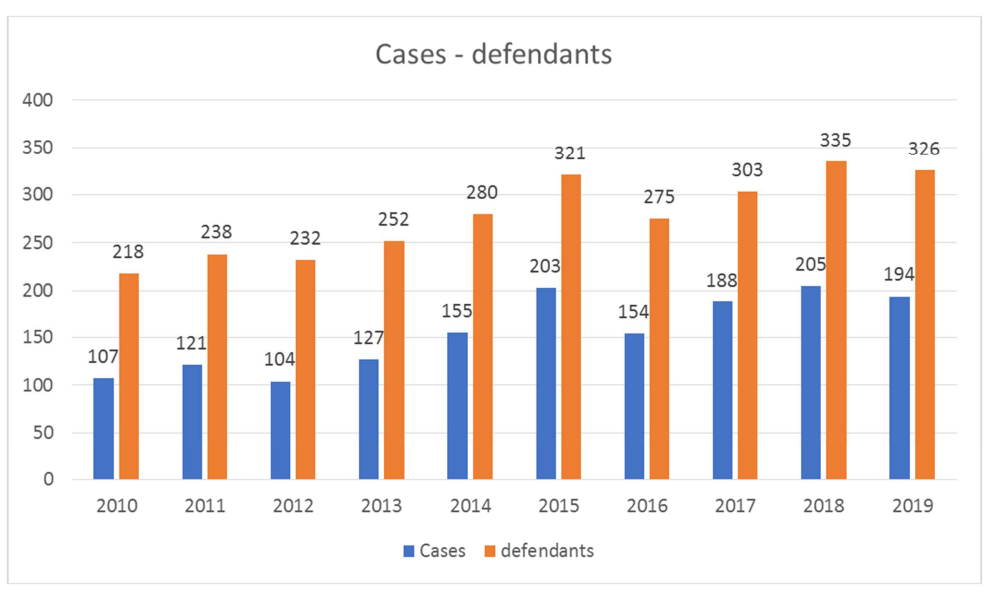

Source: Ministry of Public Security of Vietnam.

Figure 2. Number of corruption cases in the capital construction sector detected, investigated and handled between 2010 and 2019 in Vietnam.

\subsection{Corruption Tricks in the Field of Capital Construction in Vietnam}

Construction industry in Vietnam has complex characteristics, going through many stages and phases to create a construction that creates corrupt and negative behaviors that are easy to generate in the stages of operation [20]. Construction activities, through research of typical cases which have been investigated and tried in Vietnam in the past time, show that corrupt acts in the field of capital construction are often expressed in the following forms:

Giving bribes to people in positions of authority to win projects or obtaining favorable terms during project implementation and contract payment

This is a common corruption practice in capital construction in Vietnam recently. The subjects participating in the bidding 
find ways to meet people for positions of authority, then meet and agree on giving and taking bribes, the terms of guarantee between the parties, the amount of money received. In the case of Huynh Ngoc Sy, he took bribes at the East-West Boulevard Project Management Board and Ho Chi Minh City water environment. Agreement to give bribes for design consultancy contract, project implementation process, Japanese PCI Company won the design consultancy package and was appointed to supervise the bidding package.

Knowing that Japan would fund ODA for this project, the PCI leadership sought to approach Mr. Huynh Ngoc Sy (East West Highway Project Management Director-the decision maker). After the two sides agreed on an agreed price of US $\$ 900,000$ for bribes for the design consultant package, PCI continued to ask Mr. Huynh Ngoc Sy to supervise the bidding package without going through bidding. Total of 2 times is 1.7 million USD. According to Japanese and Vietnamese investigation agencies' documents, during the process of bidding and winning bids, designating contractors or executing projects, PCI's staff gave 7 times of paying bribes. for Mr. Sy. As a result, all parties' goals have been achieved [5].

In the above case, to achieve bidding packages without going through bidding as prescribed, the subjects of PCI Company-Japan bribed money to Mr. Huynh Ngoc Sy. However, to detect and prosecute objects in the case is very difficult. In all negotiations and receiving money, Huynh Ngoc Sy is always alert and only contact with one person, there is no third person and leaves no autograph when delivering. In addition, when detected crooked objects, denied the crime to the end. These are difficulties in detecting and prosecuting corruption in the construction sector [20].

Colluding with partners to rise the value of a bidding package in construction to cease illegally the properties

This trick is performed for the investor who has State budget capital with partners in procurement, construction and equipment contracts in the bidding packages. Subjects immediately implement economic contracts and raise bid packages to usurp the State Budget [1]. According to a report of the Vietnam Economic Police Department, the Ministry of Public Security showed that many cases in the field of capital construction were colluded by subjects raising bid packages to appropriate the difference. Corruption in the implementation of Song Hong Thermal Power Plant by Nguyen Van Tuyen (Director of Hoang Anh Vinashin Shipbuilding Industry Joint Stock Company) and Nguyen Tuan Duong (Chairman of the Company's Board of Directors Cuu Long investment) is a typical example. In this case, the people colluded to raise $30 \%$ of the value of machinery equipment. The amount that the partner supplied for the goods received was USD 13,730,710, but the voucher of the Cuu Long Company showed that the total amount paid to the partner was USD 14,796,613. The subjects in this case have claimed US \$ 1,065,903 [6].

These irregularities, including acts of corruption at the industrial conglomerate Vietnam Shipbuilding (Vinashin) resulting in losses to the State budget thousands of billion dong comes from the loose in the management of Group leaders This includes not strictly observing the conclusion of the Vietnamese Government Inspectorate about losses in the investment process but also seeking to conceal it. Thereby acts of corruption arise, development causing loss of thousands billion VND from the State [21].

Counterfeiting contracts to embezzle assets and withdraw works to appropriate property

This trick is often colluded by objects in ODA-funded projects or public-private investment projects, fake contracts such as supervision consultancy contracts, rental contracts, repair contracts, procurement... In addition, the trick of intestinal construction works to appropriate properties in the field of construction is a common practice today and takes place in all construction works [22]. In Vietnam, the construction subjects often change their norms, structures, types of supplies and equipment attached to the project in order to appropriate properties. Typically, in the case of embezzlement in Construction A2, Kim Giang Ward, Thanh Xuan District, Hanoi, the police investigation agency of Hanoi Police caught the case of Hoang Thanh Uyen, Team Leader of Competition Team. No. 8, Construction Company No. 1 of the General Import Export and Construction Corporation of Vietnam is instructing construction workers to pour concrete piles 64 and 86, according to the design, each pile has four vertical steel cages. and has a depth of $43 \mathrm{~m}$. Actual inspection at the site showed that the above piles had only 2 steel cages at the top and absolutely no steel at $23 \mathrm{~m}$ below the bored piles. This behavior seriously affects the quality of works, as well as the lives of its users $[9,16]$.

In addition to these common behaviors, corruption in the construction industry is also evident in behaviors that occur during the procurement process, including; Procurement, bidding lower, overpaying, bid fraud, individuals or organizations doing work without qualifications/experience/training... [23]. Corruption trends commonly found in the industry include [23-25]; bribes to win contracts; design costs increase consultant fees and contractor profits; Designed to support a specific contractor; Incomplete design leaves room for changes that can be manipulated; excessive estimation of costs to create momentum for future fund transfers; intentionally reducing cost estimates to win a bid; colluding between contractors to allocate contracts and raise prices; submit false information/documents; Create a general contract by sending multiple bids from the same contractor under different names. Akinsola and Omolayo have identified corruption trends in developing countries, including Vietnam including: prices, bribes for planning permission, illegal employment, concealment bribes, collusion between contractors, bribes to get contracts, leak information to bidders for incentives, production of illegally issued invoices, false or exaggerated complaints to contractors to prevent or reduce silos payments, including false costs for contract requirements, bribes from construction contracts to obtain operating and maintenance contracts [25]. Nepotism refers to the act of an individual in a position of favor for a relative or friend without regard to professional qualifications [26, 27]. Patronage is considered to be a form of bias wherever an individual is 
offered a job, award contract or other benefits regardless of their rights or qualifications and is often connected or personal linkages [28].

\subsection{Consequences of Corruption in the Field of Capital Construction in Vietnam}

Corruption is a very dangerous crime, many countries see corruption as a "national accident" as an "inland enemy", which slows down the socio-economic development in countries, a threat to security nation [7]. Corruption in infrastructure construction causes damage in many respects, namely:

Corruption causes economic damage

According to a report by the Ministry of Construction, corruption, loss in the construction sector currently accounts for about $30 \%$ of investment capital in Vietnam [9]. In 2019, the Construction Inspectorate conducted inspections in 31 projects with a total capital of 17,300 billion VND, all 31 projects occurred loss and waste with the amount of up to 2,070 billion VND [13]. According to data reported by the Economic Police Department-Ministry of Public Security of Vietnam, in the past 10 years (2010-2019), the Economic Police force has investigated corruption cases in the field of mechanical construction [18]. Village, with a total damage value of VND 4,710.4 billion, an average of about VND 471 billion per year, and tends to increase in the period of 2013-2016, a significant decrease in 2017 and an increase in Increase again in 2018 and 2019 (Figure 3).

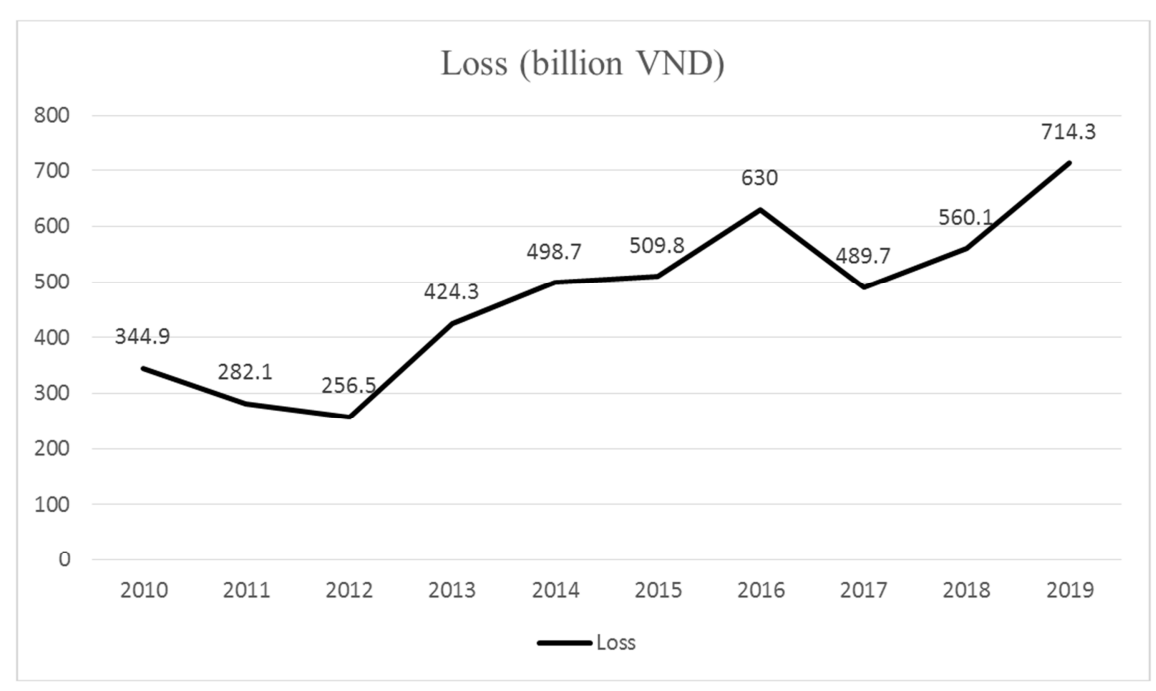

Figure 3. Value of damages in corruption cases in the field of capital construction in Vietnam from 2010 to 2019 (Source: Summary report of 2010-2019, Department of Public Security, Ministry of Public Security).

\section{Corruption causes distrust among the people}

The Document of the 9th Conference of the Central Committee of the Communist Party of Vietnam, 10th Session, clearly states: "... What makes the people still have many discontent, anxiety and annoyance today is the bureaucracy, corruption, waste, degradation of ideology, politics and quality, morality, lifestyle of a part of cadres and party members are still very serious..." [2]. Thus, the Communist Party of Vietnam has identified corruption as one of four threats to the survival of the revolutionary regime: "weakening the apparatus of the Party and the State. People's faith in the Party and the regime is eroded". Corruption affects the lives of people. Through a number of cases of exclusion of construction works such as in the A2 Building project, the price of apartment buildings has been reduced due to the people's confidence in construction activities of the Investor.

Corruption causes social inequality

From the appropriation of money and property in buildings, many officials get rich quickly. With subsidence living at a high level compared to the average income of a society, the gap between rich and poor will be increasing and one of the major risks leading to social inequality in Vietnam.

\subsection{Anti-corruption Solutions in Capital Construction in Vietnam}

In order to improve the effectiveness in preventing corruption in the infrastructure construction field in Vietnam, it is necessary to have comprehensive and feasible solutions. In particular, it is necessary to study and learn about anti-corruption solutions in this field in other countries around the world. Transparency International in 2006 recommends the following tools to combat corruption trends in the pharmaceutical industry and this can also be adapted to the construction industry according to Oyewobi include: Transparency; Rules of dignity; Protection of whistleblowers; Reduce the need for corruption; Conflicts of interest; Treaty of Integrity and Debate; Strict prosecution [24]. Hawkins points out that the following ways can prevent corruption in the construction industry:

To separate profit and labor costs from the ratio of materials and equipment in the invoice in terms of quantity. This gives more transparency to contractors.

To increase payment term to reduce petty corruption.

To select new forms of contract to promote risk allocation and opening accounting books based on actual costs. 
To find a way to use the bank account for the project whereby all contractors, subcontractors and supervision consultants are paid from a single authorized bank account. This makes sponsors and procurement units more transparent in payment.

To separate the role of supervising engineer by appointment.

To consider community supervision training to observe the progress and quality of the project [6].

For countries with developing economy like Vietnam, according to Master Degree Nguyen Xuan Truong has proposed six measures to reduce corruption may be applied in the building include:

To complete legal mechanisms and policies, renewing cadre work in management of capital construction investment projects, enhancing the role of agencies, organizations and supervision of the Party in the struggle Anti-corruption.

To promote administrative reform in the construction industry, contributing to limit and eliminate the conditions that generate corruption.

Publicly transparent the operation of the organization and transparency of income assets of officials and employees related to the field of Construction.

To improve Vietnam's legal system of anti-corruption in fields, including construction.

To strengthen activities of inspection, examination and audit in construction, and strictly handle corruption cases in the construction field.

To enhance international cooperation, implementing the UN Convention against corruption in fields, including the field of Capital Construction [1].

From the solutions mentioned by domestic and foreign authors to reduce the current corruption situation, including construction field. From the research results and the fact that corruption cases in the construction field have occurred in Vietnam recently, it is necessary to carry out the following urgent measures to minimize this situation:

To promote ethical and ideological education for cadres in charge of construction in the field of capital construction in Vietnam in order to raise awareness in the observance of guidelines and policies of the Party and laws. of the State in construction investment activities. Do not allow objects to use bribed material benefits to falsify construction investment activities.

To strengthen the inspection and control of construction activities, so that corruption cannot be detected when the works are completed, then it is very difficult in the expertise and overcoming consequences..

The functional agencies assigned the responsibility of managing should promote their role well in preventing the crime of corruption and loss at works such as: Public Security Agency, Ministry of Construction Inspectorate, Tax Inspectorate...

To enhance the transparency and transparency of construction investment projects such as information about the Investor, the construction unit, the monitoring unit...

For large projects, it is necessary to sum up and draw experience after conducting the acceptance before putting it into use from project formulation to project completion.

\section{Research Results}

Findings from research in the field of capital construction in Vietnam show that the most common corruption tactic is to give bribes to people with positions and powers to win bids for construction works, expenditures. Such fees will be offset in the process of construction, including: reducing the number of employees, removing the work, changing the structure of materials as well as replacing with cheap and old equipment and equipment in the process of building (accounting rate $44 \%$ ). In addition, there is a collusion procedure between the parties to increase the cost, to increase the value of raw materials in each item for works using the State Budget. Tricks collusion is common in phases, the phases of construction activities in order to create the fake contract, contract to usurp control of assets (accounting rate 22\%). During the pre-acceptance test and operation of a building, the corruption acts are shown in the agreement and the profit sharing between the engineer and the construction supervisor to ignore the specifications that are lower than the permitted standard of the work. build that. Acts of counterfeiting and repair contracts to corruption in construction accounting rate $18 \%$ and a number of other acts of corruption (16\%).

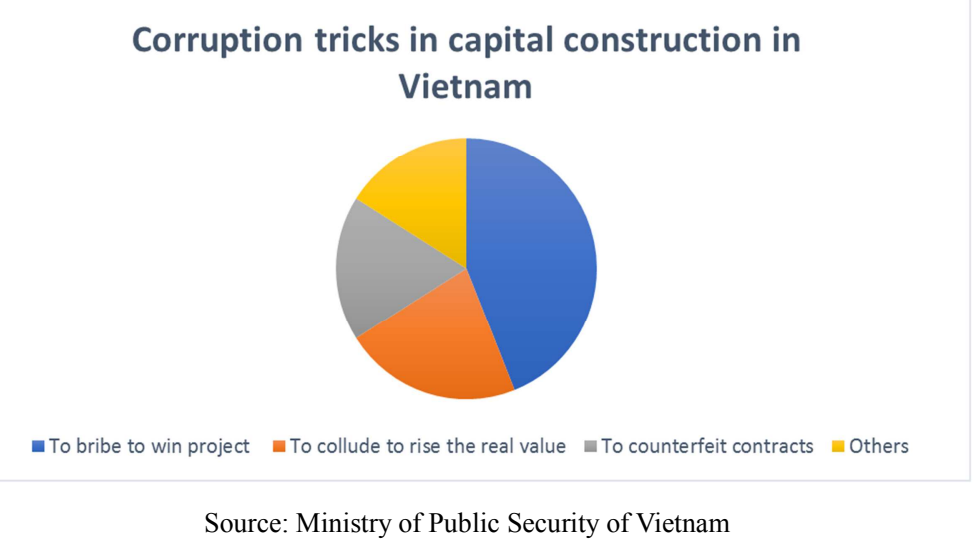

Figure 4. Corruption tactics in the field of capital construction in Vietnam in cases from 2010 to 2019. 


\section{Discussion}

Corruption in the field of capital construction in Vietnam in recent years has caused great damage to the country's economy and has a more sophisticated tactic to hide the discovery of the authorities fighting against it. Especially in the booming period of the 4.0 technology revolution in Vietnam today, the tricks of the subjects are also more sophisticated.

Based on the study of tricks of corrupt subjects in the field of capital construction in recent years in Vietnam, the main trick is still linking and colluding between objects to be able to perform acts. This comes from the management of assets in construction activities in Vietnam managed by many units, so it is difficult for a human being to commit corrupt acts. Research has shown that corruption in capital construction needs collusion between the objects and stakeholders to implement this behavior.

Previous studies on corruption behaviors have not been associated with the characteristics of the capital construction sector in Vietnam, so the introduction of anti-corruption measures associated with the capital construction sector is still general, not tied to a specific field. body and responsibilities of specific people.

From the data presented on the tricks of corruption and the consequences of this behavior, in the coming time, corruption will be more sophisticated and more complex, associated with scientific and technological applications. construction activities and in payment activities of the parties. In addition, during the period of strong international cooperation, foreign partners will see Vietnam as a country with potential for investment and headquarters, which leads to the development of infrastructure. These are opportunities but there are also potential risks of corruption in the construction process in Vietnam.

The article presents a number of new solutions stemming from the practice of corruption in Vietnam and the current tricks of corruption in the field of capital construction. If this solution is implemented synchronously, it will bring high results in preventing corruption in the field of capital construction. However, the research results are still subjective of the writer, the assessment has not fully covered all corruption cases in Vietnam in recent years but only relatively in a certain extent. Therefore, there should be independent studies of other authors on topics related to the content of the article so that the authors will have more data to offer more applicable solutions in the future.

\section{Conclusion}

The fight against corruption in Capital Construction in Vietnam is a very difficult and complex task. This stems from the typical characteristics of the field of capital construction such as: going through many stages, many stages to create works, cumbersome administrative procedures and applying-giving mechanism still exist. now in approving projects in Vietnam that facilitate corruption to arise and develop. Besides, the legal system of construction in Vietnam still has many gaps and shortcomings, law enforcement agencies have not been effective in fighting corruption crimes in the field of construction. That affects the prevention of corruption crimes in this area.

The introduction of specific solutions to prevent corruption in the field of capital construction in Vietnam is now an extremely urgent requirement to ensure national security and preserve social order and safety. The research has approached a number of solutions of domestic and international authors. In those solutions, the transparency of assets of agencies, organizations and individuals with positions and powers related to the field of capital construction is one of the solutions that need to be implemented soon to minimize the situation. Corruption occurs in this area.

\section{References}

[1] Nguyen Xuan Truong: Preventing corruption crime involving foreign elements in the context of globalization, international integration, National Political Publishing House, Hanoi, 2012.

[2] Vietnamese Communist Party: Resolution of the 12th Congress of the Vietnamese Communist Party, Hanoi, 2016.

[3] Emeka E. Okafor: Corruption and implications for industrial development in Nigeria, African Journal of Business Management, 2013, 2916-2924.

[4] Oladele, K: Causes and consequences of corruption: The Nigerian experience (1) Fighting Corruption. Journal of Political Science and Leadership, 2013, 22-36. Retrieved from www.unodc.org.

[5] Central Department of Internal Affairs: Report on investigation results of Huynh Ngoc Sy case accepting bribes at East-West Boulevard Project Management Board, Hanoi, 2012. 1-12.

[6] Central Department of Internal Affairs: Report on investigation results of corruption cases at Vinashin Economic Group, Hanoi, 2012, 1-10.

[7] Central Department of Internal Affairs: Workshop: "Recovery of Corruption Assets-Vietnamese Practices and International Experience", Hanoi, 2015, 28-35.

[8] Nguyễn Như Ý: Vietnamese dictionary, Thuan Hoa Publishing House, Hanoi, 2010.

[9] Ministry of Construction: Annual report, Hanoi. 2010-2019.

[10] Government: Report on anti-corruption activities from 2010 to 2019, Hanoi, 2010-2019.

[11] Idise, C: Impact of corruption on national development. Scholarly Information. Mixed Free World Press, Themes, 2011, 209-215.

[12] Government: Reviewing 10 years of implementation of the Anti-Corruption Law, Hanoi, 2016.

[13] Ministry of Construction: Summary report on construction activities for the period of 2014-2019, Hanoi, 2019, 1-23. 
[14] Vietnam Report: https://vietnamreport.net.vn/, 2010-2019.

[15] Vu Van Hien: V. I. Lenin with the fight against bureaucracy, corruption and the manipulation of the Communist Party of Vietnam, Hanoi, 2020.

[16] Ha Thi Hong Lan: Difficulties and problems in the fight against corruption crimes in our country today, Hanoi, 2013, 29-35. Journal of Administrative Police on Social Security No. $8+$ 9/2013.

[17] National Assembly Supervision Delegation: Summary report on industrial construction for the period of 2016-2019, Hanoi, 2019, 1-15.

[18] Economic Police Department, Ministry of Public Security: A summary report for the year 2010-2019, Hanoi, 2010-2019.

[19] Nguyen Thi Thuy (2015) Difficulties and problems of judicial expertise in a number of cases of corruption causes and solutions, Hanoi, 2015. http://noichinh.vn/nghien-cuu-trao-doi/201502/kho-khan-vumac-crab-jail-dinh-tu-phap-in-a-number-vu-tham-velvet-nguy en-nhan-phan-phap-296978/.

[20] Tran Xuan: Determining the responsibility of the leader in corruption cases, Hanoi, 2020. http://csnd.vn/Home/An-ninh-trat-tu/3132/Xac-dinh-trach-mul ti-user-content-in-office-operations-with-corruption.

[21] Dang Cong Thanh: Opposing the point: Vietnam cannot fight against corruption successfully", Theoretical Journal of People's Public Security, Hanoi. 2019, 45-51. (http://hvctcand.edu.vn/chong-dien-bien-hoa-binh/phan-bac-q uan-diem-viet-nam-khong-the-dau-tranh-chong-tham-berry-ba r-990-).
[22] Thanh Huong: China: Anti-corruption with a transnational scale, Hanoi, 2016. http://csnd.vn/Home/Quoc-te/2568/Trung-Quoc-Chong-thamnhung-voi-quy-mo-xuyen-quoc-gia.

[23] Al-Sweity, A. Y: Unethical conduct among professionals in construction industry. Master's Thesis of The Islamic University Gaza, 2013, 38-47.

[24] Oyewobi, LO, Ganiyu, BO, Oke, AA, Ola-Awo, AW \& Shittu, AA: Determinants of unethical performance in Nigerian construction industry. Journal of Sustainable Development, 4 (4), 2011, 175-182.

[25] Akinsola, O. E. \& Omolayo, O. H: Corruption and fraud in the Nigerian construction sector. The transformation of the building industry-Possibilities and realities. 43rd Annual General Meeting and Conference of Nigeria Institute of Building Held at Conference Centre, 2013, 26-30.

[26] Adewole, K. K., Oladejo, J. O. \& Ajagbe, W: Incessant collapse of building in Nigeria: The possible role of the use of inappropriate cement grade/strength class. World Academy of Science, Engineering and Technology, International Journal of Civil, Structural, Construction and Architectural Engineering, 8 (7), 2014, 818-820.

[27] Abiola A. ADEYEMO and Benedict AMADE: Corruption and Construction Projects in Nigeria: Manifestations and Solutions, PM World Journal, 2016, 1-14.

[28] Thirlwall AP: Growth and Development: With Special Reference to Developing Economies. London: Macmillan Educational Ltd, 1989. 